\title{
EFEKTIVITAS KONSELING KOGNITIF-PERILAKU DENGAN TEKNIK LATIHAN ASERTIF UNTUK MENGATASI TINDAKAN KEKERASAN PADA ANAK
}

\author{
Mubiar Agustin, Ipah Saripah,\& Asep Deni Gustiana \\ Email : mubiar@upi.edu \\ PGPAUD Universitas Pendidikan Indonesia \\ JI. Dr. Setiabudhi No. 229 Bandung 40154 Jawa Barat
}

\begin{abstract}
Abstrak: Penelitian ini beranjak dari masalah yang paling fundamental dalam kegiatan pendidikan anak usia dini khususnya di Taman Kanak-kanak (TK) yaitu masih banyaknya kesalahan perlakuan yang dilakukan oleh guru dalam kegiatan pembelajaran yang menjurus pada tindakan kekerasan. Penelitian bertujuan untuk menghasilkan konseling kognitif-perilaku dengan teknik pelatihan asertif yang tepat, teruji dan komprehensif untuk menangani tindakan kekerasan pada anak. Penelitian ini dilakukan pada tahun pelajaran 2015-2016 dengan menggunakan metode eksperimen quasi. Subjek dalam penelitian ini adalah anak kelompok B dari TK Al Muqoddasah Kab. Bandung. Hasil penelitian menunjukkan: (1) tindakan kekerasan di TK terjadi dalam berbagai bentuk mulai dari fisik, verbal, hingga relasional; (2) program konseling kognitif perilaku dengan teknik latihan asertif untuk mengatasi tindakan kekerasan dipandang layak untuk diujicobakan menurut para pakar; dan (3) terdapat pengaruh yang signifikan dari kegiatan konseling kognitif-perilaku dalam mengeliminir tindak kekerasan pada anak.
\end{abstract}

Kata-kata Kunci: konseling kognitif-perilaku, teknik pelatihan asertif, tindakan kekerasan pada anak

\section{THE EFFECTIVITY OF COGNITIVE-BEHAVIOR COUNSELLING WITH ASSERTIVE TECHNIQUE TO ADDRESS CHILD ABUSE}

\begin{abstract}
This research is based on the most fundamental problem in teaching young learners, especially in preschool, which is the tendency of the children's behavior within each other in the learning process that leads to abuse. One of the offered solutions to address abuse is to provide preventive act through Cognitive-Behavior Counselling activities with Assertive Training Technique. The aim of this research is to conduct cognitive-behavior counselling activities with assertive training technique in way that is correct, tested and comprehensive to address child abuse. The research was conducted by applying quasi experimental method in the year of. 2015 - 2016 in Bandung District. The subject of the research was group B students of Al Muqoddasah Preschool Bandung District. The result shows that: (1) the forms of child abuse consist of physical, verbal and relational abuse; (2) cognitive-behavior counselling activities with assertive training technique to address abuse are considered appropriate to implement by experts; and (3) there is a significant impact of cognitive-behavior counselling activities in minimize child abuse.
\end{abstract}

Keywords: cognitive-behavior counselling, assertive training technique, child abuse

\section{PENDAHULUAN}

Dunia anak adalah dunia bermain. Bermain memberikan kesempatan kepada anak untuk mengespresikan diri secara bebas dengan diri, teman dan lingkungannya. Maka, tidak salah jika seorang penyair berkebangsaan Lebanon bernama Khalil Gibran menggambarkan anak seperti kupu-kupu yang bebas terbang ke sana ke mari tanpa ada yang menghalangi. Sayangnya, dunia anak yang penuh keceriaan tersebut terancam dengan maraknya aksi kekerasan. Anak-anak selalu menjadi korbannya.
Sudah tidak terhitung jumlah korban kekerasan pada anak ini. Berita yang dilansir dari Komisi Perlindungan Anak Indonesia (KPAI) menunjukkan angka peningkatan tindakan kekerasan pada anak dari tahun ke tahun.

Sebenarnya jika menggunakan kacamata psikologi, fenomena kekerasan ini sudah disampaikan oleh ahli psikologi, filsafat dan sosiologi kelahiran Frankfurt Main Jerman bernama Erich Fromm. Fromm menyebut istilah kekerasan dan anarkis 
ini dengan sebutan nekrophilia (necrophilious character type), yaitu tipe orang yang tertarik dan berpenampilan pada segala bentuk kematian. Mereka senang berbicara penyiksaan, kematian dan penguburan. Lebih jauh, mereka sangat terikat dengan kekuatan dan kekuasaan. Mereka percaya pada satu cara menyelesaikan permasalahan, yaitu dengan kekerasan. Mereka umumnya rasialis, teroris, penghasut, tukang "jagal orang", dan penyiksa orang yang tak berdosa. Nekrophilia merupakan perilaku yang berbahaya. Nekrophilia memperlihatkan perilaku destruktif dengan mengeksploitasi dan merusak orang lain atau benda-benda serta alam lingkungan (Budiraharjo.ed, 2001).

Sangat dapat dimaklumi jika anak selalu menjadi korban kekerasan. Setidaknya ada dua faktor penyebab. Pertama, anak mudah dirayu, sehingga mudah diperdaya. Banyak anak-anak yang menjadi korban kekerasan karena mudah terperdaya dengan rayuan berupa pemberian makanan, uang ataupun diajak jalan-jalan. Kedua, anak adalah pribadi yang lemah sehingga selalu menjadi objek penderita tindak kekerasan. Banyak kasus kekerasan yang dialami anak disebabkan kelemahan ini, sehingga tidak sedikit anak yang mengalami kekerasan berakhir dengan tragis, kematian dan atau trauma akut.

Berdasarkan hasil monitor dan evaluasi terhadap 1.026 responden anak di sembilan daerah di Indonesia, KPAl juga menemukan bahwa $87,6 \%$ anak pernah mengalami kekerasan di sekolah dalam berbagai bentuk. Kekerasan yang paling banyak dilakukan oleh teman sekelas $(42 \%)$, guru $(29,9 \%)$, dan teman lain kelas (28\%).

Hasil monitor dan evaluasi KPAI tersebut sejalan dengan hasil studi pendahuluan yang dilakukan Saripah (2006) terhadap 18 orang guru di 5 Kabupaten dan Kota di Jawa Barat. Berdasarkan hasil wawancara, sebanyak 13 orang guru $(72,22 \%)$ melihat adanya bullying di kelas dan sisanya sebanyak 5 orang guru $(27,78 \%)$ mengaku tidak pernah melihat adanya bullying di kelas mereka. Sementara itu, guru yang menganggap bullying yang terjadi pada masa anak-anak sebagai hal yang wajar dan yang menganggap sebagai hal yang harus dihindari berjumlah sama yakni masing-masing 9 orang $(50 \%)$.

Tindakan kekerasan yang menjurus pada tindakan anarkis sekaligus kriminal khususnya pada anak tentu membutuhkan penanganan dan solusi yang tepat. Sebab bagi anak tindakan kekerasan yang mereka alami mengakibatkan berbagai dampak negatif (di luar dampak yang paling parah, yaitu kematian). Dampak tersebut dapat berupa dampak jangka pendek, yaitu dampak yang muncul seketika itu juga ketika anak mengalami kekerasan. Seperti munculnya rasa takut yang berlebihan, menarik diri dari kehidupan sosial, bila kekerasan berupa kekerasan emosional, maka akan muncul rasa ketidaknyamanan (merasa tertekan batin), stres bahkan frustrasi dan bila kekerasan berupa fisik, maka anak akan merasa kesakitan. Dampak jangka panjang yaitu kondisi yang muncul dalam jangka waktu yang cukup lama setelah kejadian kekerasan atau bahkan dapat melekat selama hidupnya. Dampak jangka panjang ini dapat berupa: trauma terhadap hal-hal yang dirasakan berhubungan dengan kekerasan yang pernah dialaminya, perasaan curiga yang berlebihan (paranoid) pada orang-orang disekitarnya, antisosial, hilangnya kepercayaan diri, stres berat sampai dengan depresi, dan kecacatan fisik permanen, bila kekerasan dilakukan berlebihan (Cavanagh \& Levitov, 2002).

Salah satu solusi yang ditawarkan untuk mengatasi permasalahan yang berkembang di atas adalah dengan menerapkan program konseling kogntitif-perilaku dengan teknik latihan asertif. Latihan asertif sangat penting pada kasus tindakan kekerasan. Anak-anak yang mengalami tindakan kekerasan umumnya tidak mampu untuk asertif sehingga sangat wajar apabila mereka menjadi korban tindakan kekerasan. Kasandra (2003) menandaskan bahwa Konseling Kognitif-Perilaku dengan teknik Latihan Asertif cukup dapat dihandalkan dalam mengatasi permasalahan psikologi seseorang termasuk didalamnya permasalahan traumatik korban tindakan kekerasan. Manfaat program pelatihan asertif ini akan membantu anak untuk lebih terampil dan tegas dalam mengatasi bahaya tindakan kekerasan yang mungkin akan menimpa mereka.

Konseling kognitif-perilaku didasarkan pada konsep mengubah pikiran dan perilaku negatif yang sangat mempengaruhi emosi. Melalui konseling kognitif-perilaku, mahasiswa terlibat aktivitas dan berpartisipasi dalam latihan untuk diri mereka dengan cara membuat keputusan, penguatan diri dan strategi lain yang mengacu pada self-regulation (Matson \& Ollendick, 1988).

Teori kognitif-perilaku (Oemarjoedi, 2003) pada dasarnya meyakini pola pemikiran manusia terbentuk melalui proses Stimulus-Kognisi-Respon 
(SKR), yang saling berkaitan dan membentuk semacam jaringan SKR dalam otak manusia, di mana proses kognitif menjadi faktor penentu dalam menjelaskan bagaimana manusia berpikir, merasa dan bertindak.

Tujuan konseling kognitif-perilaku (Oemarjoedi, 2003) yaitu mengajak individu untuk menentang pikiran dan emosi yang salah dengan menampilkan bukti-bukti yang bertentangan dengan keyakinan mereka tentang masalah yang dihadapi. Konselor diharapkan mampu menolong siswa untuk mencari keyakinan yang sifatnya dogmatis dalam diri siswa dan secara kuat mencoba menguranginya.

Dalam proses terapi, beberapa ahli konseling kognitif perilaku berasumsi bahwa masa lalu tidak perlu menjadi fokus penting dalam konseling. Oleh sebab itu, konseling kognitif-perilaku dalam pelaksanaannya lebih menekankan kepada masa kini dari pada masa lalu, akan tetapi bukan berarti mengabaikan masa lalu. Konseling kognitif-perilaku tetap menghargai masa lalu sebagai bagian dari hidup siswa dan mencoba membuat siswa menerima masa lalunya, untuk tetap melakukan perubahan pada pola pikir masa kini untuk mencapai perubahan di waktu yang akan datang. Oleh sebab itu, CBT lebih banyak bekerja pada status kognitif saat ini untuk dirubah dari status kognitif negatif menjadi status kognitif positif (Oemarjoedi, 2003)

Metode perlakuan dalam konseling kognitifperilaku sering disebut dengan istilah teknik, prosedur, dan strategi. Konseling kognitif-perilaku memiliki banyak teknik yang diambil dari pendekatan perilaku dan kognitif yang diterapkan secara kombinatif. Menurut Laidlaw et al. (2003) beberapa teknik konseling kognitif-perilaku adalah latihan asertif, pemodelan, gladi perilaku, meditasi dan relaksasi, latihan praktik, kontrak perilaku, desentisisasi sistematik, pengelolaan diri, pemecahanan masalah, penghentian pikiran, restrukturisasi kognitif, dan pengelolaan stres.

Rose and LeCroy (2004) menjelaskan bahwa strategi pokok intervensi perilaku kognitif adalah assertion training, cognitive restructuring, modeling, dan operant procedures. Selanjutnya, Mahoney \& Arnkoff (2003) membagi teknik kongseling kognitif-perilaku ke dalam tiga kategori, yaitu: (a) restrukturisasi kognitif, mencakup terapi emotifrasional, pengajaran diri, dan terapi kognitif; (b) terapi keterampilan menangani situasi, meliputi pemodelan, tertutup, latihan pengelolaan kecemasan, dan suntikan stres; dan (c) terapi pemecahan masalah; meliputi pemecahan masalah behavioral dan science personal.

Matson \& Ollendick (1988) prosedur CBT yang umum digunakan adalah 'coping skills therapies, cognitive restructuring therapies, rational emotive therapies, problem-solving therapies, selfinctructional training, dan self-control procedure'. Semua prosedur ini memiliki perbedaan dalam tiga hal yaitu; aspek pengalaman kognitif (misalnya belief, expectations, coping self-statement, images, problem-solving cognitions), muatan intervensi (kognitif, afektif, perilaku, konsekuensi), dan strategi intervensi.

Tindak kekerasan pada anak adalah perilaku salah baik dari orang tua, pengasuh, ataupun orang lain di sekitarnya dalam bentuk perlakuan kekerasan terhadap fisik dan mental yang termasuk di dalamnya adalah penganiayaan, penelantaran dan eksploitasi, mengancam, serta hal buruk lainnya yang berpengaruh terhadap fisik dan mental anak (Tower, 2003).

Dalam konteks dunia pendidikan, khususnya persekolahan, tindak kekerasan yang dilakukan oleh teman sebaya dikenal dengan sebutan bullying. Istilah bullying merujuk pada perilaku agresif yang dilakukan berulang-ulang oleh seorang atau sekelompok siswa yang memiliki kekuasaan, terhadap siswa atau siswi lain yang lebih lemah, dengan tujuan menyakiti orang tersebut (Olweus, 2005; Coloroso, 2006). Berdasarkan definisi tersebut dapat disimpulkan bahwa perilaku bullying sebenarnya telah sangat meluas di dunia pendidikan tanpa terlalu disadari bentuk dan akibatnya. Telah sejak lama dunia pendidikan mengenal istilah perpeloncoan, gencetgencetan, pemalakan, penindasan, intimidasi, dan sebagainya. Persentase terbesar kejadian bullying berada pada lingkungan sekolah dasar dan sekolah menengah pertama (Gunawan, 2006). Olweus (2005) bahkan mengungkapkan: "Bullying behavior is evident even in preschool and the problem peaks in middle school." Pernyataan ini didukung oleh fakta bahwa akhir-akhir ini perilaku bullying telah menjadi trend dan mulai ditiru oleh anak-anak yang lebih muda, seperti SMP, SD, maupun TK.

Hasil studi Saripah (2006) terhadap 526 orang siswa SD di 5 Kabupaten dan Kota di Jawa Barat menunjukkan bahwa bullying menjadi masalah terbesar yang dihadapi siswa SD dalam bidang sosial, yakni sebesar $42,59 \%$. Sebanyak 224 orang 
siswa mengaku sering diganggu, diejek, dimintai uang dan dikucilkan oleh teman atau kakak kelasnya di sekolah. Sementara itu, siswa yang membentuk kelompok atau gang di sekolah mencapai 130 orang atau $24,71 \%$.

Tindak kekerasan pada anak dapat terjadi dalam berbagai bentuk dan terentang dari yang terlihat secara fisik hingga ke bentuk perlakuan yang secara tidak disadari sebagai kekerasan. Secara umum, tindak kekerasan dapat dikelompokkan menjadi tiga, yakni (a) kekerasan fisik, (b) verbal, dan (c) emosional atau yang dikenal juga dengan psychological maltreatment.

Pertama, tindak kekerasan fisik. Termasuk jenis ini ialah mencubit, menjewer, menyentuh, meraba-raba atau memegang (dengan maksud pelecehan seksual), memukuli, mencekik, menyikut, meninju, menendang, menggigit, mencakar, serta meludahi anak yang ditindas, mendesak hingga ke posisi yang menyakitkan, merusak serta menghancurkan, atau merebut barang-barang milik anak yang tertindas.

Kedua, tindak kekerasan verbal. Tindakan ini berupa julukan nama, celaan, fitnah, kritik kejam, penghinaan (baik yang bersifat pribadi, kelompok maupun rasial), pernyataan-pernyataan bernuansa pelecehan seksual, teror, surat, e-mail atapun sms yang mengintimidasi, tuduhan-tuduhan yang tidak benar, kasak-kusuk yang keji dan keliru, gosip dan lain-lain.

Ketiga, tindak kekerasan emosional (pengabaian). Termasuk ke dalam tindakan ini adalah mengasingkan atau menolak seorang teman atau bahkan untuk merusak hubungan persahabatan. Tindak kekerasan emosional merupakan pelemahan harga diri si korban secara sistematis melalui pengabaian, pengucilan, pengecualian atau penghindaran. Perilaku ini dapat mencakup sikapsikap yang tersembunyi seperti pandangan yang agresif (melotot), lirikan mata, gerakan alis, anggukan kepala ke atas, helaan nafas, bahu yang bergidik, cibiran, tawa mengejek dan bahasa tubuh yang kasar.

Tindakan kekerasan yang menjurus pada tindakan anarkis sekaligus kriminal khususnya pada anak tentu membutuhkan penanganan dan solusi yang tepat. Sebab bagi anak tindakan kekerasan yang mereka alami mengakibatkan berbagai dampak negatif (di luar dampak yang paling parah yaitu kematian). Dampak tersebut dapat berupa dampak jangka pendek, yaitu dampak yang muncul seketika itu juga ketika anak mengalami kekerasan. Seperti munculnya rasa takut yang berlebihan, menarik diri dari kehidupan sosial, bila kekerasan berupa kekerasan emosional, maka akan muncul rasa ketidaknyamanan (merasa tertekan batin), stres bahkan frustrasi dan bila kekerasan berupa fisik, maka anak akan merasa kesakitan. Dampak jangka panjang yaitu kondisi yang muncul dalam jangka waktu yang cukup lama setelah kejadian kekerasan atau bahkan dapat melekat selama hidupnya. Dampak jangka panjang ini dapat berupa: trauma terhadap hal-hal yang dirasakan berhubungan dengan kekerasan yang pernah dialaminya, perasaan curiga yang berlebihan (paranoid) pada orang-orang di sekitarnya, antisosial, hilangnya kepercayaan diri, stres berat sampai dengan depresi, dan kecacatan fisik permanen, bila kekerasan dilakukan berlebihan (Cavanagh \& Levitov, 2002).

Salah satu solusi yang ditawarkan untuk mengatasi permasalahan yang berkembang di atas adalah dengan menerapkan program konseling kogntitif-perilaku dengan teknik latihan asertif. Latihan asertif sangat penting pada kasus tindakan kekerasan. Anak-anak yang mengalami tindakan kekerasan umumnya tidak mampu untuk asertif sehingga sangat wajar apabila mereka menjadi korban tindakan kekerasan. Oemarjoedi (2003) menandaskan bahwa Konseling Kognitif-Perilaku dengan teknik Latihan Asertif cukup dapat diandalkan dalam mengatasi permasalahan psikologi seseorang termasuk didalamnya permasalahan traumatik korban tindakan kekerasan. Manfaat program pelatihan asertif ini akan membantu anak untuk lebih terampil dan tegas dalam mengatasi bahaya tindakan kekerasan yang mungkin akan menimpa mereka.

Teori kognitif-perilaku (Oemarjoedi, 2003) pada dasarnya meyakini pola pemikiran manusia terbentuk melalui proses Stimulus-Kognisi-Respon (SKR), yang saling berkaitan dan membentuk semacam jaringan SKR dalam otak manusia, di mana proses kognitif menjadi faktor penentu dalam menjelaskan bagaimana manusia berpikir, merasa dan bertindak. Tujuan konseling kognitif-perilaku (Oemarjoedi, 2003) adalah mengajak individu untuk menentang pikiran dan emosi yang salah dengan menampilkan bukti-bukti yang bertentangan dengan keyakinan mereka tentang masalah yang dihadapi. Konselor diharapkan mampu menolong siswa untuk mencari keyakinan yang sifatnya dogmatis dalam diri siswa dan secara kuat mencoba menguranginya. 


\section{METODE PENELITIAN}

Pendekatan yang digunakan dalam penelitian ini adalah pendekatan kuantitatif dengan metode kuasi eksperimen. Kelompok kontrol dan eksperimen adalah anak-anak kelompok B pada TKAl Muqoddasah Kabupaten Bandung. Pengujian efektivitas konseling ini menggunakan Nonequivalent Control Groups Design, di mana tidak melakukan random dalam menentukan kelompok eksperimen dan kontrol. Tabel 1 berikut adalah desain penelitian uji keefektifan konseling kognitif-perilaku dengan teknik latihan asertif untuk menangani tindakan kekerasan pada kelompok eksperimen dan kontrol (nonequivalent control groups design)

Tabel 1. Desain Penelitian

\begin{tabular}{lccc}
\hline Kelompok & Pretest & Perlakuan & Postest \\
\hline Eksperimen & $\mathrm{O}_{1}$ & $\mathrm{X}$ & $\mathrm{O}_{3}$ \\
Kontrol & $\mathrm{O}_{2}$ & & $\mathrm{O}_{4}$ \\
\hline
\end{tabular}

Keterangan :

$\mathrm{O}_{1}$ : pretes kelas eksperimen

$\mathrm{O}_{2}$ : pretes kelas kontrol

$\mathrm{O}_{3}$ : postes kelas eksperimen

$\mathrm{O}_{4}$ : postes kelas kontrol

$\mathrm{X}$ : pembelajaran kontekstual
Subjek dalam penelitian ini adalah anak usia Taman Kanak-kanak pada kelompok B pada TK AIMuqoddasah I dan II Kab. Bandung Tahun Pelajaran 2015-2016 yang berjumlah 36 anak.

Sesuai dengan tahap penelitian sebagaimana dikemukakan sebelumnya yang meliputi: (a) survei lapangan terhadap kondisi awal gejala dan jenis kekerasan yang cenderung dialami oleh anak Taman Kanak-kanak. Pada kegiatan ini instrumen yang digunakan adalah angket tentang area bentuk kekerasan; (b) uji coba pengembangan konseling kognitif-perilaku dengan teknik latihan asertif di Taman Kanak-kanak. Pada sesi ini instrumen yang digunakan adalah angket tentang rancangbangun konseling kognitif perilaku dengan teknik latihan asertid yang bersifat hipotetik yang mencakup (1) rasional, (2) tujuan, (3) asumsi, (4) langkah-langkah kegiatan, (5) kompetensi guru, dan (6) evaluasi; dan (c) uji validasi program konseling kognitif perilaku dengan teknik hasil pengembangan. Instrumen yang digunakan pada tahap ini adalah angket tentang kecerdasan jamak anak dengan menggunakan metode eksperimen quasi saat menerapkan pre dan post test.

\section{HASIL DAN PEMBAHASAN}

\section{Hasil Penelitian}

\section{a. Gambaran Umum}

Berdasarkan hasil angket terbimbing yang diberikan kepada anak usia Taman Kanak-kanak pada kelompok B pada TK Al-Muqoddasah I dan II Kab. Bandung Tahun Pelajaran 2015-2016 diperoleh dambaran umum tindak kekerasan sebagaimana digambarkan pada tabel 1 berikut.

Tabel 1. Gambaran Umum Tindakan Kekerasan pada Anak di TK Al-Muqoddasah Kab. Bandung

\begin{tabular}{cllc}
\hline NO & \multicolumn{1}{c}{ DIMENSI } & \multicolumn{1}{c}{ INDIKATOR } & PERSENTASE (\%) \\
\hline 1 & Tindak Kekerasan Fisik & Dicubit pada bagian anggota tubuh & 12 \\
& & Dipukul pada bagian anggota tubuh & 31 \\
& Dicakar pada bagian muka & 2 \\
& Ditendang pada bagian anggota tubuh & 1 \\
& Diludahi dengan sengaja & 0 \\
& Barang/mainan direbut & 54 \\
& Dijuluki oleh anak lain & 63 \\
& & Dicela oleh anak lain & 30 \\
& Dindak Kekerasan Verbal & \multicolumn{2}{c}{5} \\
& Dituduh oleh anak lain & 2 \\
& & Dipelototi oleh anak lain & 3 \\
& & Diketawakan (diejek) oleh anak lain & 78 \\
& & Diabaikan saat berbicara & 2 \\
& & Diacuhkan saat bermain & 13 \\
& & Didorong oleh anak lain & 4 \\
\hline
\end{tabular}


b. Program Konseling Kogntif Perilaku dengan Teknik Latihan Asertif untuk Mengatasi Tindakan Kekerasan pada Anak di TK Al-Muqoddasah Kab. Bandung

Berdasarkan hasil uji validasi kepada dua orang pakar Bimbingan dan Konseling Anak, program Konseling Kogntif Perilaku dengan teknik latihan asertif untuk mengatasi tindakan kekerasan pada anak di TKAl-Muqoddasah Kab. Bandung dipandang layak untuk diujicobakan. Lebih lanjut, hasil uji validitas program disajikan pada tabel 2 di bawah ini.

Tabel 2. Hasil Uji Validasi Program

\begin{tabular}{clc}
\hline NO & \multicolumn{1}{c}{ ASPEK } & KETERANGAN \\
\hline 1 & Rasional & Memadai \\
2 & Tujuan & Memadai \\
3 & Asumsi & Memadai \\
4 & Lamgkah-langkah & Memadai \\
5 & Kompetensi Guru & Memadai \\
6 & Evaluasi & Memadai \\
\hline
\end{tabular}

c. Efektivitas Program Konseling kogntif Perilaku dengan Teknik Latihan Asertif untuk Mengatasi Tindakan Kekerasan pada Anak di TK AlMuqoddasah Kab. Bandung

Hasil uji efektivitas Program Konseling kogntif Perilaku dengan Teknik Latihan Asertif untuk Mengatasi Tindakan Kekerasan pada Anak di TK Al-Muqoddasah Kab. Bandung diperoleh dengan membandingkan antara pretes dan postes, sebagai berikut.

\section{a. Pretest}

Hasil U-Test untuk data pretest dapat dilihat pada tabel 2 di bawah ini.

Tabel 2. Hasil Uji Beda Kelompok Eksperimen dan Kontrol Pada Saat Pretest

\begin{tabular}{lr}
\multicolumn{2}{c}{ Test Statistics $^{\mathrm{b}}$} \\
\hline \multicolumn{2}{c}{ PRETEST } \\
\hline Mann-Whitney U & 157.500 \\
Wilcoxon W & 328.500 \\
Z & -.143 \\
Asymp. Sig. (2-tailed) & .886 \\
Exact Sig. [2*(1-tailed Sig.)] & $.888^{\mathrm{a}}$ \\
\hline
\end{tabular}

a. Not corrected for ties.

b. Grouping Variable: TINDAK KEKERASAN

Data hasil pengamatan sebelum diberikan perlakuan selanjutnya diolah dengan menggunakan
SPSS. 17.0 dengan tujuan untuk melihat ada tidaknya perbedaan antara kelompok eksperimen dan kontrol pada saat pretes. Seperti yang telah dipaparkan di metode penelitian, bahwa teknik analisis data yang digunakan adalah U-Test atau Mann Whitney Test. Hipotesis Penelitian:

Ho: $\mu \_1 \leq \mu \_2$, Tidak terdapat perbedaan yang signifikan tindak kekerasan anak antara kelas eksperimen dan kelas kontrol sebelum perlakuan.

Ha: $\mu \_1 \geq \mu \_2$, Terdapat perbedaan yang signifikan tindak kekerasan anak antara kelas eksperimen dan kontrol sebelum perlakuan.

Pengujian signifikansi perbedaan yaitu membandingkan antara sig. dengan $(\alpha=0,05)$. Kriteria pengujiannya adalah:

Terima Hipotesis nol jika sig. $\geq \alpha(0.05)$

Tolak Hipotesis nol jika sig. $\leq \alpha(0.05)$

Berdasarkan tabel 2 di atas, diketahui nilai sig. 0,886 > $\alpha(0.05)$ maka Ho diterima, artinya tidak terdapat perbedaan yang signifikan tindak kekerasan anak antara kelompok eksperimen dan kontrol pada saat pretest.

b. Postest

Setelah subjek diberikan perlakuan, maka dilakukan pengamatan kembali untuk memperoleh data hasil postest. Selanjutnya data hasil postest di olah menggunakan U-Test. Adapun hasil pengujian data postest dapat dilihat pada tabel 3 di bawah ini.

Tabel 3. Hasil Uji Beda Kelompok Eksperimen dan Kontrol Pada Saat Postest

\begin{tabular}{lr}
\multicolumn{2}{c}{ Test Statistics $^{\mathrm{b}}$} \\
\hline \multicolumn{2}{c}{ POSTES } \\
\hline Mann-Whitney U & 67.000 \\
Wilcoxon W & 238.000 \\
Z & -3.022 \\
Asymp. Sig. (2-tailed) & .003 \\
Exact Sig. [2*(1-tailed Sig.)] & $.002^{\mathrm{a}}$ \\
\hline
\end{tabular}

a. Not corrected for ties.

b. Grouping Variable: KEKERASAN ANAK

Hipotesis Penelitian:

Ho: $\mu \_1 \leq \mu \_2$, Tidak terdapat perbedaan yang signifikan tindak kekerasan anak antara kelas eksperimen dan kelas kontrol setelah perlakuan.

Ha: $\mu \_1 \geq \mu \_2$, Terdapat perbedaan yang signifikan tindak kekerasan anak antara kelas eksperimen dan kontrol setelah perlakuan.

Pengujian signifikansi perbedaan yaitu membandingkan antara sig. dengan $(\alpha=0,05)$. 
Kriteria pengujiannya adalah:

Terima Hipotesis nol jika sig. $\geq a(0.05)$

Tolak Hipotesis nol jika sig. $\leq \alpha(0.05)$

Berdasarkan tabel 3 di atas, diketahui nilai sig. $0,003<\alpha(0.05)$ maka Ho ditolak, artinya terdapat perbedaan yang signifikan tindak kekerasan anak antara kelompok eksperimen dan kontrol pada saat postes atau setelah diberikan perlakuan. Selanjutnya untuk menentukan kelompok mana yang lebih efektif menerima perlakuan dalam mengeliminir tindak kekerasan yang dialami anak yakni dengan membandingkan nilai mean rank kelompok eksperimen dan kontrol. Perlakuan dikatakan lebih efektif apabila nilai mean rank-nya lebih besar. Adapun nilai mean rank hasil uji beda postes pada tabel 4 di bawah ini.

Tabel 4. Nilai Mean Rank Kelompok Eksperimen dan Kontrol Pada Saat Postest

\begin{tabular}{llrcc}
\hline & Kekerasan Anak & $\mathrm{N}$ & $\begin{array}{r}\text { Mean } \\
\text { Rank }\end{array}$ & Sum of Ranks \\
\hline POSTEST & Kel Eksperimen & 18 & 23.78 & 428.00 \\
& Kel Kontrol & 18 & 13.22 & 238.00 \\
& Total & 36 & & \\
\hline
\end{tabular}

Berdasarkan tabel 4 di atas, diketahui nilai mean rank kelompok eksperimen $(23,78)>$ kontrol $(13,22)$ artinya perlakuan yang diterima kelompok eksperimen lebih efektif dalam hal ini konseling kognitif-perilaku. Adapun gain tindak kekerasan anak antara kelompok eksperimen dan kontrol dapat dilihat pada gambar 1 .

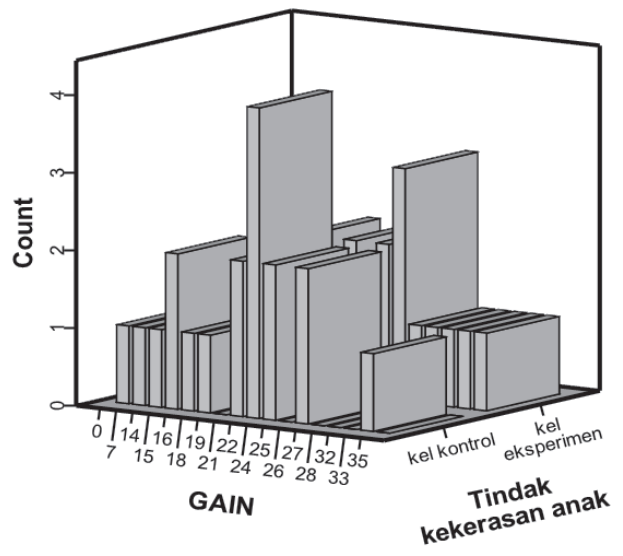

Gambar 1. Gain tindak kekerasan anak antara kelompok eksperimen dan kontrol

\section{Pembahasan}

Hasil penelitian menunjukkan, tindakan kekerasan dalam berbagai bentuk telah terjadi di tingkat Taman Kanak-kanak. Fakta ini semakin mendukung pernyataan bahwa akhir-akhir ini perilaku bullying telah menjadi trend dan mulai ditiru oleh anakanak yang lebih muda, seperti SMP, SD, maupun TK. Olweus (2005) bahkan mengungkapkan: "Bullying behavior is evident even in preschool and the problem peaks in middle school."

Pada dimensi fisik, tampak bahwa tindakan kekerasan yang paling sering dialami oleh anak TK yaitu berupa barang/mainan direbut (54\%) yang diikuti dengan dipukul pada bagian anggota tubuh (31\%).

Berebut barang/mainan seringkali dianggap sebagai kejadian yang biasa terjadi dan dilakukan oleh anak-anak dalam situasi yang normal. Peristiwa tersebut akan berubah menjadi tindakan kekerasan ketika salah seorang anak merasa menjadi tidak berdaya, lemah, teraniaya dan pada gilirannya dia akan menjadi korban. Coloroso (2006) menyatakan bahwa bullying merupakan perspektif korban yang melibatkan tindakan yang disengaja, berulang-ulang, serta ada ketidakseimbangan kekuatan antara pelaku dengan korban.

Memukul merupakan bentuk agresif lain yang juga paling sering dilakukan oleh anak-anak terutama yang berusia dini. Dari sisi fisik, tindakan memukul ini paling mudah terlihat bentuk dan dampaknya. Selain berhubungan dengan ego, alasan anak untuk cenderung memukul temannya bisa disebabkan tidak adanya pilihan aktivitas lain yang terarah. Hal ini sejalan dengan ungkapan Evans (1989, dalam Tattum, 1997) sebagai berikut: "Children with little to do during their playtime may resort to seeking adventure through various forms of illicit play - for example, fighting, teasing, and annoying other children."

Selanjutnya, pada dimensi tindak kekerasan verbal, anak TK paling sering dijuluki oleh anak lain $(63 \%)$ dan dicela oleh anak lain (30\%). Kedua bentuk perilaku ini merupakan bentuk penindasan yang paling umum digunakan baik oleh anak perempuan maupun anak laki-laki. Coloroso (2006) bahkan melaporkan bahwa kekerasan verbal ini persentasenya mencapai $70 \%$ dari seluruh kasus penindasan. Dari ketiga bentuk tindak kekerasan, kekerasan verbal merupakan salah satu jenis penindasan yang paling mudah dilakukan dan kerap merupakan pintu masuk menuju ke kedua bentuk penindasan lainnya.

Terakhir, pada dimensi tindak kekerasan relasional, anak TK melaporkan sering diketawakan 
(diejek) oleh anak lain (78\%) serta diacuhkan saat bermain $(13 \%)$. Tindak kekerasan relasional merupakan jenis yang paling sulit dideteksi dari luar. Penindasan relasional adalah pelemahan harga diri korban secara sistematis melalui pengabaian, pengecualian, pengucilan, atau penghindaran (Coloroso, 2006).

Ketiga dimensi tindak kekerasan tersebut pada umumnya terjadi di tempat bermain dan cenderung tanpa pengawasan guru. Berbagai hasil penelitian menunjukkan bahwa tempat bermain dan lapangan sekolah merupakan tempat yang paling banyak menjadi lokasi terjadinya tindak kekerasan di sekolah (Coloroso, 2006; Tattum, 1997).

Perilaku di taman bermain sendiri dapat ditinjau dari dua sudut pandang. Blatchford, 1993; Opies, 1969; Sluckin, 1981 (dalam Tattum, 1997) menyatakan dua sudut pandang tersebut sebagai perilaku "romantis" dan "bermasalah". Perilaku romantis terjadi ketika anak-anak belajar sesuatu yang positif dan menikmati bermain di tempat bermain. Adapun perilaku bermasalah muncul ketika anak memperoleh hal yang menyakitkan dan memerlukan penanganan guru untuk mengatasinya.

Tindak kekerasan termasuk ke dalam bentuk perilaku bermasalah yang muncul pada saat anak sedang bermain sehingga memerlukan penanganan yang salah satunya berupa latihan asertif. Hal ini sejalan dengan haasil penelitian Saripah (2010) yang menunjukkan bahwa anak yang menjadi korban bullying (tindak kekerasan) perlu mendapatkan bantuan untuk meningkatkan kepercayaan diri dan kemampuan asertif.

Perilaku asertif sendiri, kendatipun merupakan sesuatu yang alamiah namun perlu diajarkan dan dikembangkan terlebih pada anak usia dini (Farida, 2003). Perilaku asertif menurut Stefan (2006) merupakan ketegasan dan keberanian menyampaikan pendapat yang meliputi tiga komponen dasar, yaitu: (1) kemampuan mengungkapkan perasaan, misalnya: untuk menerima dan mengungkapkan perasaan marah, hangat, seksual; (2) kemampuan mengungkapkan keyakinan dan pemikiran secara terbuka, misalnya: mampu menyuarakan pendapat, menyatakan ketidaksetujuan dan bersikap teags, meskipun secara emosional sulit melakukan ini bahkan sekalipun kita harus mengorbankan sesuatu; (3) kemampuan untuk mempertahankan hak-hak pribadi, tidak membiarkan orang lain mengganggu dan memanfaatkan kita. Orang yang asertif bukan orang yang suka terlalu menahan diri dan juga bukan pemalu, mereka bisa mengungkapkan perasaannya secara langsung tanpa bertindak agresif atau melecehkan.

Dalam penelitian ini, perilaku asertif pada anak usia dini dilatihkan melalui model konseling kognitif perilaku dengan teknik latihan asertif untuk mengatasi tindakan kekerasan pada anak di TK Al-Muqoddasah Kab. Bandung.

Berdasarkan hasil pengolahan data, diketahui bahwa model konseling kognitif-perilaku dengan teknik latihan asertif dapat mengurangi atau mengeliminasi tindak kekerasan pada anak. Hal ini terjadi karena anak yang biasa mengalami tindak kekerasan, setelah diberikan konseling kognitif-perilaku dengan teknik latihan asertif, berani mengutarakan kejadian yang diterimanya dan menanyakan alasan perbuatan tersebut kepada pelaku. Dengan demikian, dalam hal ini korban mencoba mengubah atau modifikasi fungsi berfikir, merasa, dan bertindak dengan menekankan peran otak dalam menganalisis, memutuskan, bertanya, bertindak, dan memutuskan kembali. Dengan mengubah status pikiran dan perasaannya, pelaku diharapkan dapat mengubah tingkah lakunya, dari negatif menjadi positif. Proses tersebut sejalan dengan tujuan konseling kognitifperilaku (Oemarjoedi, 2003) adalah mengajak individu untuk menentang pikiran dan emosi yang salah dengan menampilkan bukti-bukti yang bertentangan dengan keyakinan mereka tentang masalah yang dihadapi.

Pada anak usia TK, proses perubahan pola pikir sangat perlu difasilitasi oleh guru. Dengan demikian, guru dituntut untuk menciptakan peluang yang memungkinkan siswa dapat terbuka menyampaikan segala perasaannya tanpa merasa takut ataupun malu. Guru diharapkan mampu menolong siswa untuk mencari keyakinan yang sifatnya dogmatis dalam diri siswa dan secara kuat mencoba menguranginya. Melalui fasilitasi dari guru maka anak akan dapat berkembang menjadi anak yang memiliki kemampuan asertif dan bukan pasif ataupun agresif.

\section{PENUTUP}

\section{Kesimpulan}

Berdasarkan hasil penelitian diperoleh kesimpulan sebagai berikut. Pertama, tindak kekerasan pada anak TK terjadi dalam berbagai 
bentuk, baik berupa fisik, verbail, maupun relasional. Pada dimensi fisik, anak TK mengalami barang/ mainannya direbut oleh teman dan dipukul pada bagian anggota tubuh. Pada dimensi verbal, tindak kekerasan yang sering terjadi adalah dijuluki dan dicela oleh anak lain. Adapun pada dimensi relasional, anak TK sering diketawakan (diejek) oleh anak lain dan diacuhkan saat bermain.

Kedua, berdasarkan hasil uji validasi, program konseling kognitif perilaku dengan teknik latihan asertif untuk mengatasi tindak kekerasan pada anak TK dipandang memadai dan layak untuk diujicobakan. Komponen program terdiri dari rasional, tujuan, asumsi, langkah-langkah kegiatan, kompetensi guru, dan evaluasi.

Ketiga, program konseling kognitif perilaku dengan teknik latihan asertif untuk mengatasi tindak kekerasan pada anak TK terbukti efektif. Secara kuantitatif, hal tersebut tampak dari hasil pretes dan postes yang menunjukkan perubahan signifikan. Adapun secara kualitatif tampak dari kemampuan anak untuk berani menyatakan keinginannya, menolak teman dengan cara-cara yang tepat serta mengekspresikan perasaan secara positif.

\section{Saran}

Rekomendasi penelitian ditujukan kepada pihak-pihak sebagai berikut. Pertama, bagi praktisi PAUD, yaitu berdasarkan hasil penelitian, diharapkan dapat dirumuskan model pembelajaran ataupun pedoman pembelajaran yang dapat mereduksi tindakan kekerasan pada anak. Kedua, bagi universitas diharapkan dapat mengembangkan berbagai pelatihan ataupun workshop dalam membantu lembaga persekolahan ataupun pemerintahan untuk mencegah dan mengatasi permasalahan tindakan kekerasan pada anak.

\section{DAFTAR PUSTAKA}

Budiharjo, P (ed). (1996). Mengenal teori kepribadian mutakhir. Kanisius. Yogyakarta.

Cavanagh \& Levitov. (2002). The counseling experience, a theoretical and practical approach. Waveland. Long Grove. Illinois.

Coloroso, B. (2006). Penindas, tertindas, dan penonton: Resep memutus rantai kekerasan anak dari prasekolah hingga SMU. Jakarta: Serambi IImu Pustaka.

Farida. (2006). Efektivitas pelatihan asertivitas untuk peningkatan kemampuan pemecahan masalah pada siswa. Yogyakarta: Psikologi UGM.

Komite Perlindungan Anak Indonesia. (2015). Pelaku kekerasan anak tiap tahun meningkat. (Online). Tersedia: http://www.kpai.go.id. (3 Maret 2016).

Oemarjoedi, K.A. (2003). Pendekatan cognitive behavior dalam psikoterapi. Jakarta: Penerbit Creative Media.

Olweus, D. (1993). Bullying at school: What we know and what we can do. Malde, MA: Blackwell Punlishers.

Saripah, I. (2010). Model konseling kognitif perilaku untuk memanggulangi bullying siswa. Disertasi. Bandung: Sekolah Pascasarjana Universitas Pendidikan Indonesia. (tidak diterbitkan).

Stefan, S. (2006). Menanamkan sikap asertif di sekolah (Online). http://www.indomedia.com/ poskup/2006/10/14/edisi14/opini.htm http:// groups.yahoo.com/group/pakguruonline/ message/2400.

Tattum, D., et. al. (1997). Understanding and managing bullying. Oxford: Heinemann Educational Books. 